\title{
Analysis of Radiative Properties and Direct Radiative Forcing Estimates of Dominant Aerosol Clusters over an Urban-Desert Region in West Africa
}

\author{
Olusegun G. Fawole ${ }^{1,2^{*}}$, Xiaoming $\mathrm{Cai}^{2}$, Rachel T. Pinker ${ }^{4}$, A.R. MacKenzie ${ }^{2,3}$ \\ ${ }^{1}$ Department of Physics and Engineering Physics, Obafemi Awolowo University, Ile-Ife 220005, Nigeria \\ ${ }^{2}$ School of Geography, Earth and Environmental Sciences, University of Birmingham, B15 2TT, UK \\ ${ }^{3}$ Birmingham Institute of Forest Research (BIFoR), University of Birmingham, B15 2TT, UK \\ ${ }^{4}$ Department of Atmospheric and Oceanic Science, University of Maryland, College Park, MD 20742, USA
}

\begin{abstract}
The strategic location of the AERONET site in Ilorin, Nigeria, makes it possible to obtain information on several aerosol types and their radiative effects. The strong reversal of wind direction occasioned by the movement of the ITCZ during the West Africa Monsoon (WAM) plays a major role in the variability of aerosol nature at this site, which is confirmed by aerosol optical depth (AOD) $(675 \mathrm{~nm})$ and Ångström exponent (AE) $(440-870 \mathrm{~nm})$ values with $1^{\text {st }}$ and $99^{\text {th }}$ percentile values of 0.08 and 2.16, and 0.11 and 1.47 , respectively. The direct radiative forcing (DRF) and radiative forcing efficiency (RFE) of aerosol, as retrieved from the AERONET sun-photometer measurements, are estimated using radiative transfer calculations for the periods of 2005-2009 and 2011-2015. The DRF and RFE of the dominant aerosol classes - desert dust (DD), biomass burning (BB), urban (UB) and gas flaring (GF) - have been estimated. The median ( \pm standard deviation) values of the DRF at the top of the atmosphere (TOA) for the DD, BB, UB and GF aerosol classes are $-27.5 \pm 13.2 \mathrm{Wm}^{-2},-27.1 \pm 8.3 \mathrm{Wm}^{-2},-11.5 \pm 13.2 \mathrm{Wm}^{-2}$ and $-9.6 \pm 8.0 \mathrm{Wm}^{-2}$, respectively, while those of the RFE are $-26.2 \pm 4.1 \mathrm{Wm}^{-2} \delta^{-1},-35.2 \pm 4.6 \mathrm{Wm}^{-2} \delta^{-1},-31.0 \pm 8.4 \mathrm{Wm}^{-2} \delta^{-1}$ and $-37.0 \pm 10.3 \mathrm{Wm}^{-2} \delta^{-1}$, respectively. Arguably due to its high SSA and assymetric values, the DD aerosol class shows the largest DRF but the smallest RFE. Its smallest AOD notwithstanding, the GF class can cause greater perturbation of the earth-atmosphere system in the sub-region both directly and indirectly, possibly due to the presence of black carbon and other co-emitted aerosol and the ageing of the GF aerosols. This study presents the first estimate of DRF for aerosols of gas flaring origin and shows that its radiative potential can be similar in magnitude to that of biomass burning and urban aerosol in West Africa.
\end{abstract}

Keywords: Gas flaring; West African Monsoon; Direct radiative forcing; Radiative forcing efficiency; Assymetric parameter.

\section{INTRODUCTION}

Atmospheric aerosols perturb the earth's radiative energy balance both indirectly and directly on regional and global scales (Charlson et al., 1992; Haywood and Shine, 1995; Rana et al., 2009). The ability of the aerosols to alter the amount of radiation depends on their concentration, composition, and particle size distribution (Verma et al., 2017). All of these determining factors vary significantly with aerosol sources. Increased concentrations of anthropogenic aerosols in the atmosphere since the pre-industrial times has been suggested to be partly responsible for the onset of global warming (IPCC, 2013).

When perturbation of the radiative budget of the earth-

\footnotetext{
${ }^{*}$ Corresponding author.

E-mail address: gofawole@oauife.edu.ng
}

atmosphere system results from the scattering and absorption of incoming solar radiation by atmospheric aerosol, the resulting radiative forcing is termed Direct Radiative Forcing (DRF). When atmospheric aerosols absorb radiation, they eventually dissipate such radiation, thereby altering the microphysical properties and lifetime of clouds, which invariably affect precipitation. Forcing resulting from such alterations is termed Indirect Radiative Forcing (IPCC, 2013). The contribution of aerosol to the total forcing due to well-mixed greenhouse gases is still associated with large uncertainties (Myhre, 2013).

The West African climate has a unique weather pattern due to the West African Monsoon (WAM) which is characterised by large-scale seasonal reversals of wind regimes (Sultan and Janicot, 2000; Barry and Chorley, 2009). The movement of the Intertropical Convergence Zone (ITCZ) and Intertropical front (ITF) are responsible for the seasonal reversal of the prevailing wind pattern in the region. Deep convection occurs in organised systems referred to as 
Mesoscale Convective System (MCS) (Mathon and Laurent, 2001). MCSs associated with the ITCZ can lead to rapid uplift and large scale redistribution of aerosols (Reeves et al., 2010).

In recent years, in the West African region, anthropogenic emissions of aerosols and gaseous pollutants have increased substantially, largely due to increasing population and industrialisation, a trend expected to continue until 2030 (Liousse et al., 2014). Dominant anthropogenic sources of aerosol at the study site are fossil fuel combustion, vehicular emission, biomass burning, and industrial emission while the dominant natural aerosol source is desert dust. Despite growing evidence in support of the impacts of anthropogenic aerosols on regional radiative budget, strict regulations on emissions are still not available in major African cities and, where they are available, they are very weak (Liousse et al., 2012).

In Nigeria, the various wind patterns and seasons are associated with different dominant aerosol types. While the north-easterly Harmattan (NEH) wind, pre-dominant in the dry season (November-February), brings desert dust and biomass burning aerosols into the region, the Southwesterly Monsoon (SWM) wind, associated with the onset of the WAM (April-October), brings predominantly urban and industrial aerosol which are believed to contain more carbonaceous aerosols (Knippertz et al., 2015). The properties and concentrations of these aerosol types vary significantly with the wind pattern. Studies of atmospheric aerosol and their radiative effects are very scarce in Nigeria.

In this study, the radiative properties of key aerosol types at this urban-desert station were analysed and their DRF and RFE at the TOA was estimated to provide the first estimate of climate forcing of gas-flaring aerosols in the region.

\section{METHODOLOGY}

\section{Description of the AERONET Site and Prevailing Climatic Condition}

The Ilorin AERONET site $\left(8.32^{\circ} \mathrm{N}, 4.34^{\circ} \mathrm{E}\right)$ is located at a site between the densely populated monsoonal forest region of the south and Sahel Savannah region of the north. There is pronounced variation in the climatic conditions of the region governed by the movement of the Intertropical Convergence Zone (ITCZ) and Intertropical Front (ITF), which are responsible for the seasonal reversal of the wind direction (the West African Monsoon (WAM)).

The WAM is a coupled atmosphere-ocean-land system which is characterised by summer rainfall and winter drought (Lafore et al., 2010). The rainfall in the West African subregion results essentially from the northward movement of the low-level monsoon airflow from March to August and the southward retreat from September to November. At their northern-most position, the humid monsoonal wind from the south meet drier and warmer air to form the ITF (Cornforth, 2012). During the dry season (NovemberFebruary), the West African sub-region experiences strong emissions of pollutants resulting from extensive biomass burning of vegetation often from land preparation for the incoming planting season. During the wet season (May to
October), the region is strongly influenced by mesoscale convective systems (MCSs), which affects the compositions of the atmosphere through several ways including rapid vertical transport of aerosols to the upper troposphere (Law et al., 2010; Mari et al., 2011).

Gas flaring is a prominent and persistent source of atmospheric aerosols which includes soot (black carbon), $\mathrm{SO}_{2}, \mathrm{CO}, \mathrm{NO}_{\mathrm{x}}\left(\mathrm{NO}+\mathrm{NO}_{2}\right), \mathrm{PAH}$ and VOCs, especially in the oil-rich regions of the world (Fawole et al., 2016a). There are over 300 active flare sites in the region where an estimated 23.7 (44.4 metric tons of $\mathrm{CO}_{2}$ equivalent) and 15.1 (28.3 metric tons of $\mathrm{CO}_{2}$ equivalent) billion cubic meters (bcm) of natural gas was flared in 2006 and 2008, respectively (Elvidge et al., 2011; Fawole et al., 2016a). In 2012 , of the 325 active flare sites identified in the Nigerian oil field, $97(\sim 30 \%)$ ranked among the top 1000 largest flares out of the 7467 identified globally (Elvidge et al., 2015).

\section{Trajectory Calculation and Classification}

Seven-day (168 hours) back trajectories were calculated using the UK's Universities Global Atmospheric Modelling Programme (UGAMP) offline trajectory model. The model is driven by six-hour ERA-Interim (European Centre for Medium-Range Weather Forecasts Interim Re-Analysis) wind analyses data. The trajectories of particles are calculated backward in time by interpolating these wind analyses to the current particle position. The position (latitude, longitude) and pressure were output every trajectory time step of 0.6 hours. The choice of 7-day back trajectory length is due to the atmospheric lifetime of between 5 and 9 days estimated for black carbon (BC) and particulate organic matter (POM), respectively (Cooke and Wilson, 1996; Cooke et al., 1997; Stier et al., 2006; Koch et al., 2009). Both BC and POM are major constituents of aerosol in the study area.

As shown in several studies, for example, Bibi et al. (2016) and Alam et al. (2016), atmospheric aerosols could be clustered using the inter-relationships between different pairs of their microphysical and optical properties. Using similar techniques, prominent aerosol classes were identified at the study site in Fawole et al. (2016b) as: Biomass burning (BB), Desert dust (DD), Urban (UB) and Gas flaring (GF) aerosols. In terms of optical and microphysical properties, these classes vary significantly (Fawole et al., 2016b); mixed classes (DD-BB, DD-UB, GF-UB and GFDD) were also identified. Using similar clustering technique of analysing aerosol optical and microphysical properties, Bibi et al. (2016) classified aerosol in the Indo-Gangetic Plain into dust, biomass and urban/industrial aerosol classes.

In this study, the properties of the single-source dominant classes were analysed to estimate their direct radiative forcing and forcing efficiency. For details of the trajectory classification and analysis of the variation of the optical and microphysical properties of the identified aerosol classes see Fawole et al. (2016b).

\section{AERONET Data Analysis}

The absolute magnitude of aerosol radiative forcing is 
determined, predominantly, by the values of aerosol optical depth (AOD) and single scattering albedo (SSA), while its sign is dependent on the SSA and surface albedo. Both AOD and SSA vary significantly with the source of the aerosol (Pani et al., 2016). In this study, Version 3 Level 1.5 of AERONET data released in January 2018 to which improved cloud screening and new quality controls have been applied were used to estimate the DRF and RFE of anthropogenic and natural aerosol classes in the West African sub-region. Adequate knowledge of aerosol SSA, hemispheric backscatter fraction $(b)$ and AOD can be used to calculate the mean TOA aerosol radiative forcing for optically thin, partially absorbing aerosol (Haywood and Shine, 1995). For sites like Ilorin, where differences in the diurnal variation of aerosol properties (extensive and intensive) could be highly pronounced, the use of monthly averages of aerosol parameters will only provide highly generalised estimates of the optical and microphysical properties of the aerosol at such a site.

One of the key properties that determine the climate forcing ability of an aerosol is the angular distribution of the light scattered by the aerosol particles (Marshall et al., 1995). The angular distribution of scattered light intensity at a specific wavelength is referred to as the phase function $(P)$. The asymmetry parameter, $g$, an important intensive parameter of aerosols for estimating its climate forcing ability could be derived from $P$. Values of $g$ range between -1 for entirely backscattered light to +1 for entirely forward scattered light (Andrews et al., 2006). The fraction of backscattered light is the ratio of the integral of the volume scattering function over the backward half solid angle divided by the integral of the volume scattered function over the full solid angle (Horvath et al., 2016).

For AERONET retrievals, uncertainties in the direct sun measurements are within \pm 0.01 for longer wavelengths greater than $440 \mathrm{~nm}$ and \pm 0.02 for shorter wavelengths less than $440 \mathrm{~nm}$. AOD estimated uncertainty varies spectrally from \pm 0.01 to \pm 0.02 with the highest error in the ultraviolet wavelengths (Holben et al., 1998; Eck et al., 1999). For all sky radiance wavelengths (that is, 440, 675, 870, and $1020 \mathrm{~nm}$ ), the uncertainty in SSA is expected to be \pm 0.03 based on Version 1 almucantar retrieval computations (Dubovik et al., 2000; Holben et al., 2006).

\section{Relationship between the Asymmetry Parameter and the Backscatter Fraction}

Several studies, e.g., Wiscombe and Grams (1976), Marshall et al. (1995) and Kokhanovsky and Zege (1997), have attempted to parameterise the backscatter fraction $(b)$ in terms of the asymmetry parameter $(g)$. Studies estimating aerosol DRF have either adopted an approximate relation between $b$ and $g$ or look-up tables of parameterisation of aerosol optical properties such as those of Hess et al. (1998) and D'Almeida et al. (1991).

In this study, assuming spherical particles, approximate relations given in Eq. (1) as cited in Horvath et al. (2016) and Eq. (2) according to Delene and Ogren (2002) have been used to estimate backscatter fraction $(b)$ and average upscatter fraction, $\beta$, respectively. $b=\left[1.1\left(\frac{1}{1-g}\right)^{1.85}+1\right]^{-1}$

$\beta=0.0817+1.8495 b+2.9682 b^{2}$

\section{Aerosol Radiative Forcing}

Estimating Direct Radiative Forcing

The direct radiative forcing (DRF), $\Delta F$, of aerosol at the top of the atmosphere (TOA) is estimated using the expression derived by Charlson et al. (1992). According to Haywood and Shine (1995) the radiative transfer equation proposed by Charlson et al. (1992) is simplified as given in Eq. (3).

$$
\Delta F \approx-D S_{o} T_{a t}^{2}\left(1-A_{c}\right) \omega \bar{\beta} \bar{\delta} \times\left(\left(1-R_{s}\right)^{2}-\frac{2 R_{s}}{\bar{\beta}}\left(\frac{1}{\omega}-1\right)\right)
$$

where $D$ is the fractional day length, $\omega$ is the spectrally weighted single scattering albedo, $S_{o}$ is the solar constant, $T_{a t}$ is the atmospheric transmission, $A_{c}$ is the fractional cloud amount, $R_{s}$ is the surface reflectance, $\bar{\beta}$ is the spectrally weighted backscattered fraction and $\bar{\delta}$ is the spectrally weighted AOD. The critical value of SSA at which the DRF shifts from positive to negative is dependent on the surface albedo and asymmetric parameter, $g$ (Haywood and Boucher, 2000; Kassianov et al., 2007). One advantage of the analytical solution for the radiative transfer equation as stated above (Eq. (3)) over a radiative transfer model is an explicit dependence on individual parameters determining the radiative forcing (Chylek and Wong, 1995). As cloud cover $\left(A_{c}\right)$ is a parameter in Eq. (3), to use the expression, the assumption is that the cloud cover is above the aerosol layer which is a typical atmospheric condition in the region considered in this study.

Schemes of wavelength-dependent aerosol parameters are time-consuming and quite complex to be incorporated into radiative forcing calculations and radiative transfer codes that can produce representative and accurate estimates of radiative forcing with one or two wavelength regions (Blanchet, 1982). In their study to examine the possibility of replacing aerosol parameters by wavelength-independent parameters and the accuracy and representativeness of such average parameters for the complete solar spectrum, Blanchet (1982) found out that results of calculations with average parameter are in close agreement with corresponding terms at a wavelength $(\lambda)$ of $700 \mathrm{~nm}$. Haywood (1995), using detailed radiative transfer codes, tested the representativeness of average aerosol parameter and found that results at around $\lambda=700 \mathrm{~nm}$ were quite similar to those of using the entire solar spectrum. Hence, the use of aerosol parameters at $\lambda=675 \mathrm{~nm}$, which is the nearest to $700 \mathrm{~nm}$ in the range of wavelengths at which aerosol parameters are measured by AERONET sun-photometers, in our estimations.

Fractional day-length, solar constant and atmospheric transmittance are assumed to be $0.5,1370 \mathrm{~W} \mathrm{~m}^{-2}$ and 0.76 , respectively (Haywood and Shine, 1995). To estimate DRF and RFE of the different aerosol classes identified in 
Fawole et al. (2016b), monthly mean values of cloud amount $\left(A_{c}\right)$ were obtained from the ASOS-AWOS-METAR dataset (NOAA, 1998; Yang et al., 2016) for the nearest airport (Cotonou) to the site, where sufficient amount of cloud cover data are available. The surface reflectance data used are model output for albedo simulations for Ilorin (20052009) (R.T. Pinker, personal communication, August 2016). Fig. 1 presents the time series for the mean monthly surface albedo for Ilorin during 2005-2009. The yearly pattern of the variation of surface albedo (reflectance) is quite similar for the available five-year model output.

\section{Radiative Forcing Efficiency}

SSA and backscatter fraction of the particle can be used to calculate the TOA aerosol forcing $(\Delta \mathrm{F})$ per unit aerosol optical depth (AOD); this is called aerosol forcing efficiency (Sheridan et al., 2002; Kaufman et al., 2005). In this study, to compare the forcing potential of the various aerosol classes, we estimated the forcing efficiency using Eq. (4). Forcing efficiency, $(\Delta F / \delta)$, is the aerosol radiative forcing per unit AOD. AOD is a major extensive property of the aerosol, which determines the magnitude of its radiative forcing. Forcing efficiency depends only on the nature and composition of the aerosol rather than its amount (Sheridan and Ogren, 1999).

$$
\frac{\Delta F}{\delta}=-D S_{o} T_{a t}{ }^{2}\left(1-A_{c}\right) \omega \bar{\beta} \times\left(\left(1-R_{s}\right)^{2}-\frac{2 R_{s}}{\bar{\beta}}\left(\frac{1}{\omega}-1\right)\right)
$$

Virkkula et al. (2014), in their study to assess the effect of aerosol from different phases of biomass burningflaming and smouldering - on the chemical and physical properties of airborne aerosols in the boreal forest, used the expression in Eq. (4) to estimate the radiative forcing efficiency of the biomass burning aerosols. Rizzo et al.
(2013), using Eq. (4), estimated aerosol forcing efficiency over a primary forest site in Amazonia.

\section{RESULTS AND DISCUSSIONS}

\section{Climatology of Aerosol Properties}

Significant variation of aerosol optical and microphysical properties in the multiyear analysis of aerosol properties at the Ilorin AERONET site is a strong indication of the varying sources of aerosols at the site. The range of values, at $\lambda=675 \mathrm{~nm}$, for aerosol optical depth (AOD), single scattering albedo (SSA) and asymmetry parameter $(g)$ are $0.04-3.71,0.68-0.99$, and $0.58-0.8$, respectively. The variation of aerosol properties is more pronounced between the non-WAM and WAM months due to seasonal reversal of the prevailing wind direction, and hence, a change of dominant sources of aerosols.

Temporal Variability of Aerosol Optical Depth, Fine Mode Fraction and Angström Exponent

During the NEH months (November-February), the values of the aerosol optical depth $\left(\mathrm{AOD}_{675}\right)$ and Angström Exponent $\left(\mathrm{AE}_{440-870}\right)$ are $1.22 \pm 0.17$ and $0.35 \pm 0.06$, respectively. These are months of intense biomass burning in the West African sub-region as well as intrusion of dust from the Sahara and Sahel regions. Aerosol loading in the SWM months (April-October) are characterised by lower AOD (675 nm) and high AE (440-870 nm) with median values of $0.58 \pm 0.23$ and $1.02 \pm 0.19$, respectively (see Fig. 2). The monthly plots in Fig. 2 are obtained from average daily data of aerosol parameters. Compared to AE values for similar dust sites, the relatively high average $\mathrm{AE}$ value of the dust aerosol in the NEH months is probably due to contributions of biomass burning aerosol at that time of the year (Fawole et al., 2016b).

The significant seasonal pattern in the $\mathrm{AE}$ and fine mode

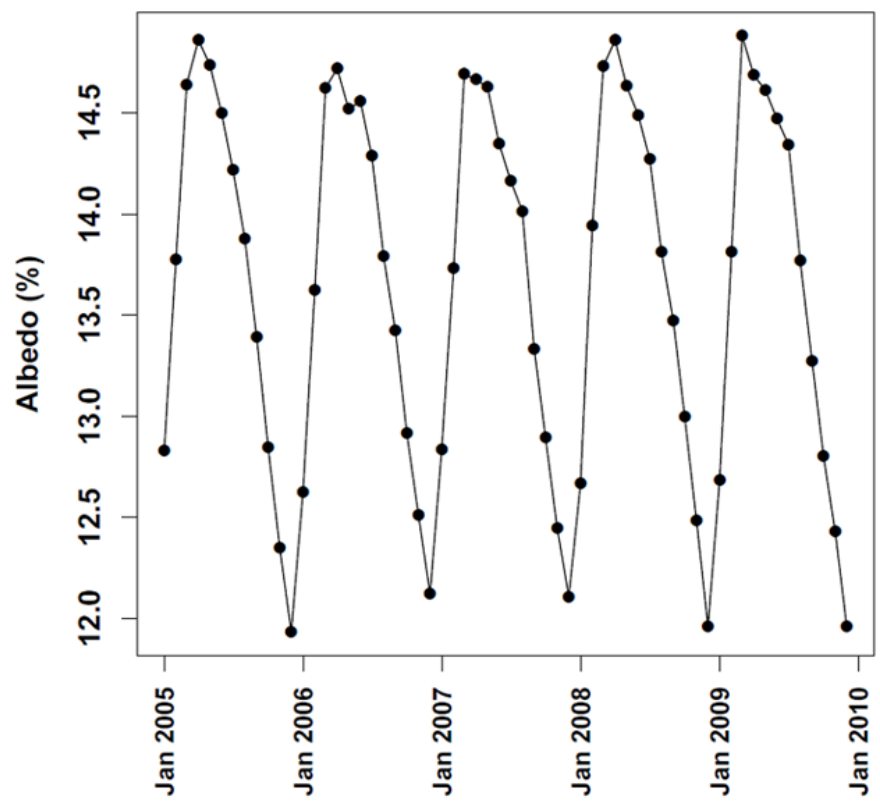

Fig. 1. Time series for monthly mean surface albedo at Ilorin for the period (01/2005-12/2009). 

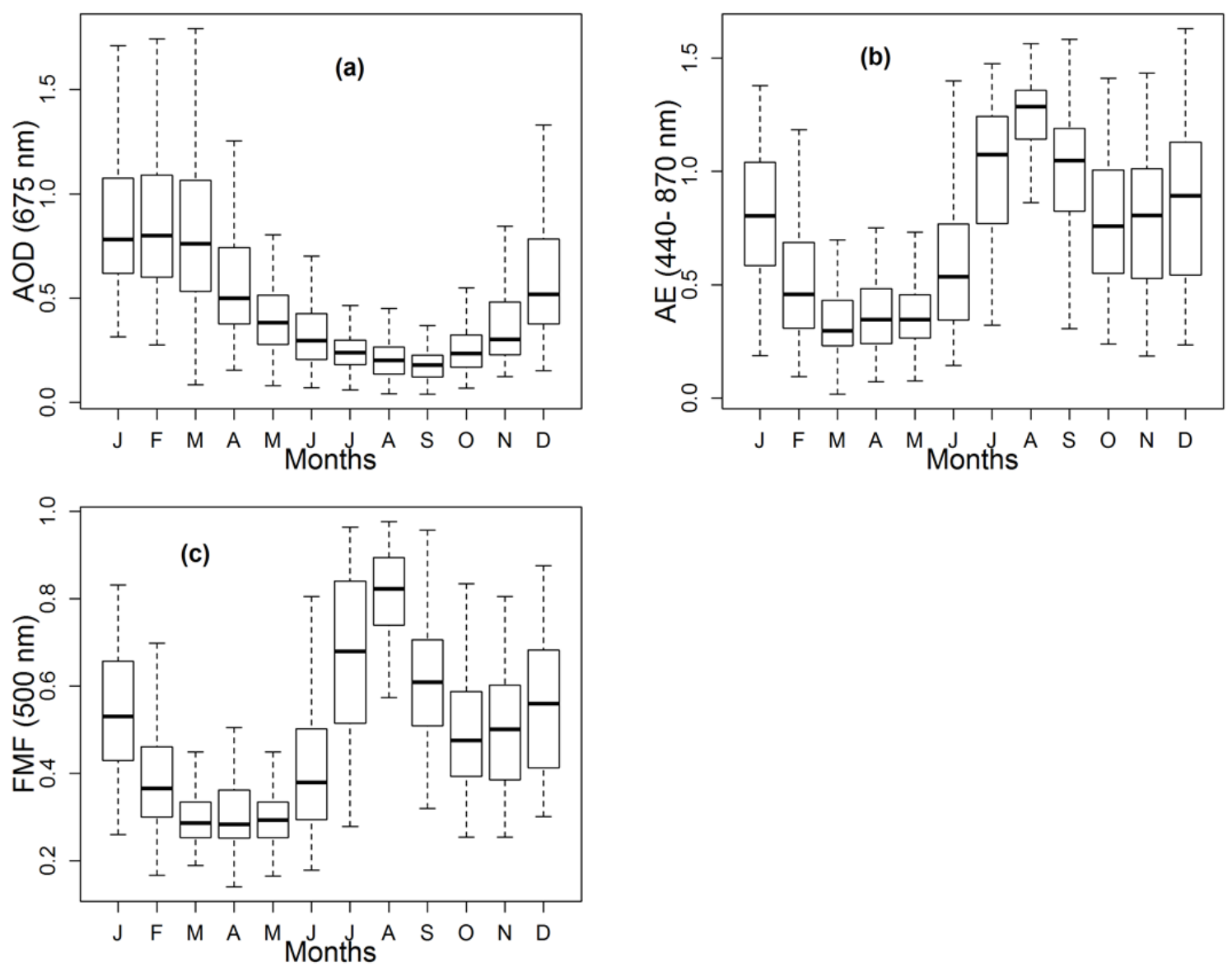

Fig. 2. Multiyear monthly variations of (a) AOD, (b) Angstrom exponent (AE), and (c) Fine Mode Fraction (FMF) of aerosol during the year 2005-2015.

fraction (FMF) of aerosol at the site, as seen in Fig. 2(b) and $2(\mathrm{c})$, is due to varying aerosol sources and/or changes in atmospheric transport. There is the dominance of fine mode aerosol fraction during the West African monsoon months when the prevailing wind is the moist SWM. The influx of urban-industrial air is expected to predominate during the WAM months, between April and October (Fawole et al., 2016b). The value of AE peaks between July and September and is lowest between February and March. The lower AE values during the peak of the dry season show the strong intrusion of dust in this region at that period of the year. During the WAM months, the peak AE values between July and September coincide with the peak values of backscatter fraction, $b$ (see Figs. 2(b) and 3(b)). This strongly suggests an increase in fine particle fraction, which is attributable to inflow of urban and industrial emissions from the south of the AERONET site. The variation of aerosol parameter with prevailing monsoonal wind as observed in this study has been observed in similar studies over Karachi, Pakistan, during the period 2006-2008 (Bibi et al., 2017) and Ahmedabad, India (Ramachandran and Kedia, 2010).

\section{Temporal Variability of Single Scattering Albedo (SSA)} and Backscatter Fraction

In the West African sub-region, there are significant differences in the relative amount of scattering and absorption of aerosols at different periods of the year. These differences result in the variation of SSA during the years as shown Fig. 3(a). During the SWM months, as shown in the multiyear mean monthly SSA values in Fig. 3(a), inland flow of south-westerly monsoon winds are rich in partially absorbing aerosols from the urban and industrial site including gas flaring emissions from the intense gas flaring activities in the Niger Delta region. In Fig. 3(a), the WAM months (AprilAugust) exhibit the widest range of SSA (0.66-0.98) which could result in a wider range of DRF. This wide range of SSA could be attributable to the diverse nature of aerosol in the urban and industrial emissions from the south of Ilorin.

The boxplots in Fig. 3(b) show a steady increase in the backscatter fraction from the lowest average values of 0.07 \pm 0.01 during March (peak of the NEH months) to the highest average values of $0.1 \pm 0.02$ during the peak of the WAM months. The median values of the backscatter fraction of the non-WAM and WAM months correspond to asymmetric parameter $(g)$ values of $0.72 \pm 0.1$ and $0.61 \pm$ 0.1 , respectively. This arguably suggests a steady increase in the concentration of fine-mode aerosol fraction during the WAM months which is attributable to increased inflow of combustion aerosols from urban and industrial emissions. Mie theory predicts a higher backscatter fraction for finemode spherical aerosol particles (Andrews et al., 2011). The wide range of backscatter fraction during the non-WAM 

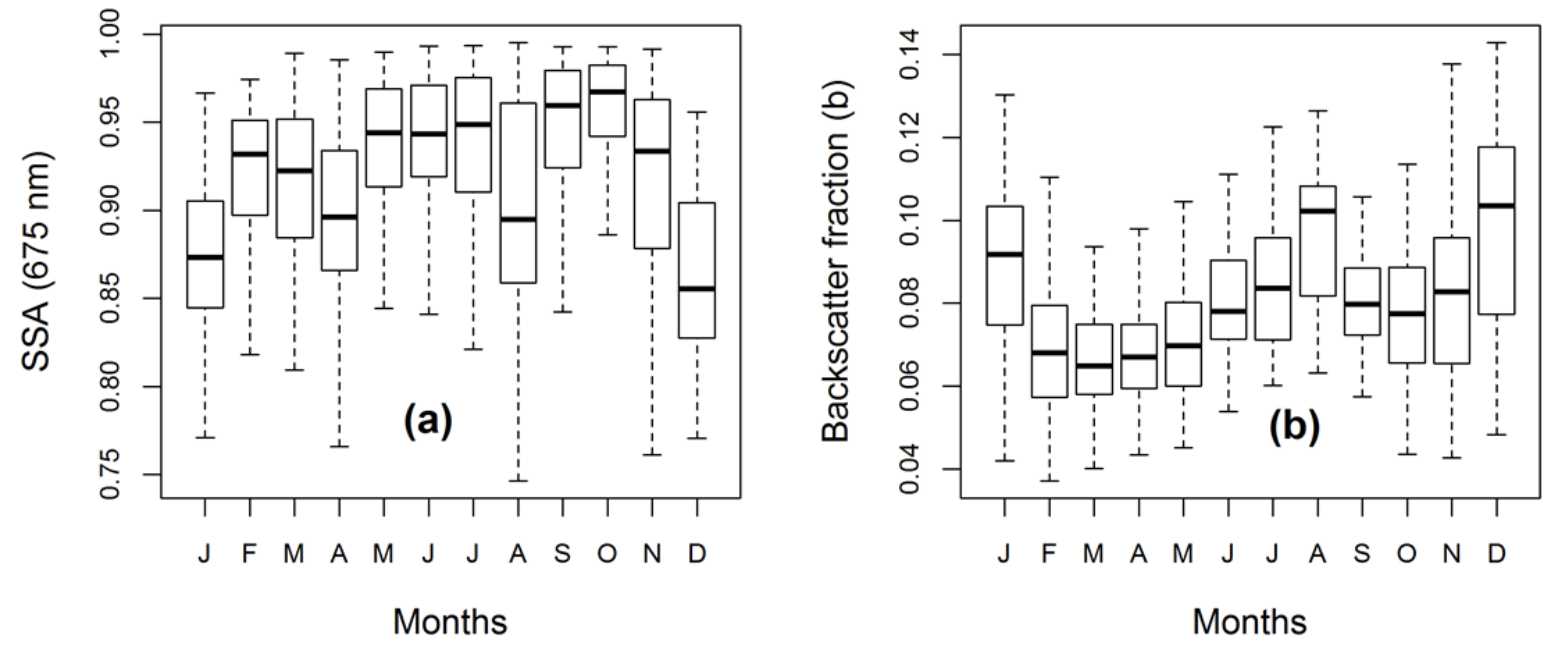

Fig. 3. Multiyear average monthly (a) variation of SSA $(675 \mathrm{~nm})$ and (b) variation of backscatter fraction during the year 2005-2015.

months (NDJF) is due to mixture of biomass burning and intrusion of desert dust which are intense during the Harmattan haze period in the region. The mean monthly value of backscatter fraction in Fig. 3(b) shows a bi-modal distribution with peaks during the intense biomass burning season (NDJ) and the peak of the WAM months (JulyAugust) when the ITCZ is northernmost allowing enhanced inland flow of aerosol from south of the AERONET site.

\section{Variability of Angström Exponent and AOD for the Aerosol Classes}

The median ( \pm standard deviation) values of the optical and microphysical properties of the identified aerosol classes are presented in Table 1. Unless otherwise stated, average values of aerosol parameters are reported at $675 \mathrm{~nm}$. The Angström exponents (AE) discussed for the aerosol classes were estimated using the $440 \mathrm{~nm}$ and $870 \mathrm{~nm}$ wavelength pair. The highly varying range of $\mathrm{AOD}_{440}$ and AE values, 0.07-3.87 and 0.01-1.74, respectively, strongly suggests a broad range of contributing sources to the aerosol loading at the study site. As the distribution of most of the aerosol parameters for the classes are non-Gaussian, the median values are reported with the standard deviations given in brackets.

\section{Desert Dust (DD)}

The DD aerosol class consists of 209 days of aerosol signals, which are predominant in the NEH months and the early days of the onset of WAM months. The major source of desert dust considered in this class classification is the
Sahara and Sahel dust regions $\left(13-18^{\circ} \mathrm{N} ; 6-17^{\circ} \mathrm{E}\right)$. The median values of $\mathrm{AOD}_{440}$ and $\mathrm{AE}_{440-870}$ for this aerosol class is $1.13( \pm 0.54)$ and $0.3( \pm 0.12)$, respectively. These values agree well with those from studies for similar sites in the Bodélé Depression of northern Chad (Todd et al., 2007), Indo-Gangetic Plain (Bibi et al., 2016) and dust regions of China (Wang et al., 2004). The average value for AOD is highest for the desert dust class while AE is the least. With a median SSA value of $0.95( \pm 0.02)$, this class is the least absorbing.

\section{Urban Aerosol (UB)}

Aerosol signature in the urban aerosol class is prominent in the WAM months when the south-westerly moist monsoon wind is prevalent in the region. For this class, the median $\mathrm{AOD}_{440}$ and $\mathrm{AE}$ values are $0.53( \pm 0.35)$ and $0.52( \pm 0.34)$, respectively. Even though this $\mathrm{AE}$ value is low, it is still higher than that for the DD aerosol class. The DD aerosol class is expected to contain a higher fraction of coarse aerosol. This class of aerosol (Urban), with a median value of SSA of $0.93( \pm 0.04)$, is partially absorbing arguably due to increased carbonaceous particle content from anthropogenic sources in the urban area.

\section{Gas Flaring Aerosol (GF)}

This class is similar to the urban class but has a lower median value of $\mathrm{AOD}_{440}$ and an average $\mathrm{AE}$ value, which is higher than that of the urban aerosol by a factor of $\sim 2$. For this class, the median values of $\mathrm{AOD}_{440}$ and $\mathrm{AE}$ values are $0.41( \pm 0.26)$ and $1.16( \pm 0.29)$, respectively. A median

Table 1. Summary of parameter for aerosol classes used to estimate their DRF.

\begin{tabular}{lllllll}
\hline & $\begin{array}{l}\text { Backscatter } \\
\text { fraction }(\mathrm{b})\end{array}$ & $\begin{array}{l}\text { AOD } \\
(675 \mathrm{~nm})\end{array}$ & $\begin{array}{l}\text { Asymmetry parameter } \\
(675 \mathrm{~nm})\end{array}$ & $\begin{array}{l}\text { SSA } \\
(675 \mathrm{~nm})\end{array}$ & $\begin{array}{l}\text { DRF } \\
\left(\mathrm{Wm}^{-2}\right)\end{array}$ & $\begin{array}{l}\text { Forcing efficiency } \\
(\mathrm{FE})\left(\mathrm{Wm} \delta^{-1}\right)\end{array}$ \\
\hline DD & $0.06 \pm 0.01$ & $0.91 \pm 0.44$ & $0.74 \pm 0.03$ & $0.97 \pm 0.02$ & $-30.3 \pm 13.4$ & $-31.0 \pm 3.3$ \\
BB & $0.1 \pm 0.02$ & $0.61 \pm 0.26$ & $0.66 \pm 0.03$ & $0.87 \pm 0.03$ & $-23.6 \pm 8.9$ & $-39.0 \pm 4.0$ \\
UB & $0.08 \pm 0.02$ & $0.38 \pm 0.23$ & $0.70 \pm 0.03$ & $0.96 \pm 0.04$ & $-11.7 \pm 7.5$ & $-32.4 \pm 5.4$ \\
GF & $0.1 \pm 0.02$ & $0.29 \pm 0.21$ & $0.66 \pm 0.04$ & $0.91 \pm 0.06$ & $-8.2 \pm 5.8$ & $-36.0 \pm 7.8$ \\
\hline
\end{tabular}


value of SSA of $0.9( \pm 0.06)$ makes it more absorbing than the urban aerosol class, which is attributable to it having a relatively higher carbonaceous particulate content. This class is estimated to have an average Absorption Angstrom Exponent (AAE) of $0.98( \pm 0.25)$ in contrast to urban aerosols, which has an AAE value of $1.2( \pm 0.38)$ (Fawole $e t$ al., 2016b). The gas-flaring region, south of the AERONET site, contains more than 300 active flares (Elvidge et al., 2015), where it is estimated that more than $25 \%$ of the annual natural gas production is flared (Elvidge et al., 2009; Ite and Ibok, 2013; Anejionu et al., 2015).

It should, however, be noted that gas flaring, a prominent source of soot $(\mathrm{BC})$, also emits other aerosol including volatile organic compounds (VOCs), $\mathrm{SO}_{2}$ and $\mathrm{NO}_{\mathrm{x}}$, some of which exert a cooling effect on the climate (USEPA, 2012).

\section{Biomass Burning}

Similar to findings from the studies by Bibi et al. (2016) and Tiwari et al. (2016), the BB aerosol class is characterised by high AOD and high AE, which is typical of biomass burning sites. Although it is prevalent almost at the same time as the desert dust season during the NEH months, it can be distinguished by its lower SSA and higher AE values. For this class, the median values of $\mathrm{AOD}_{440}$ and $\mathrm{AE}$ are $0.93( \pm 0.3)$ and $1.0( \pm 0.25)$, respectively. The range of values for $\mathrm{AOD}_{440}$ and $\mathrm{AE}$ are in agreement with values reported by Ogunjobi et al. (2008) and Pace et al. (2006) for similar biomass burning sites in West Africa and around the central Mediterranean, respectively. The regions of biomass burning considered in the classification of this class are (i) $6.5-11.5^{\circ} \mathrm{N} ; 3^{\circ} \mathrm{W}-3^{\circ} \mathrm{E}$ and (ii) $6.5-11.5^{\circ} \mathrm{N}$; $13.6^{\circ} \mathrm{E}-22.5^{\circ} \mathrm{E}$ (see Fawole et al. (2016b)). The choice of these $\mathrm{BB}$ regions are based on data obtained from MODIS active fire detection over Africa as reported by Roberts et al. (2009). In agreement with reports from previous studies from similar sites, this class, with median SSA value of $0.86( \pm 0.04)$, is the most absorbing class presumably due to its enhanced organic carbon (OC) content.

Table 2 presents the mean monthly surface reflectance, $R_{S}$, and cloud amount, $A_{C}$, used in the DRF estimation. Sources of these parameters are stated in Section 2.4.1.

\section{Aerosol Radiative Forcing}

The direct radiative forcing (DRF) for each aerosol class at the TOA was estimated using the relationship in Eq. (3). The values of surface reflectance, $R_{s}$, and cloud amount, $A_{C}$, used in the estimations range between $0.12-0.15$ and $0.15-0.39$, respectively. Table 1 presents, for each cluster, the range of values of AOD $(\tau)$, SSA $(\omega)$, backscatter fraction $(b)$ used in the DRF estimations. The daily average values of these aerosol parameters were used for the DRF estimations of the four classes.

Fig. 4 presents the variation of the DRF estimates at
TOA for each aerosol cluster. The DD aerosol class with median $\mathrm{AOD}_{675}$ value of $0.91( \pm 0.44)$ has the highest DRF of $-30.3 \pm 13.4 \mathrm{Wm}^{-2}$ at TOA. Of the four classes identified, this class has the highest mean AOD. The median DRF value for this class, as shown in Fig. 4, is highest. It is believed that this high DRF value is due to the large SSA (average value of $0.97 \pm 0.02$ ), which brings about less absorption and more scattering, and the largest asymmetry factor, $g$, of $0.74 \pm 0.03$, which causes more forward scattering of incoming radiation, compared to the other aerosol classes. Thus, consistent with the findings of García et al. (2012), this class has the most effective cooling effect on the earthatmosphere system at the TOA in the region.

The biomass burning (BB) aerosols class has an estimated DRF of $-23.6 \pm 8.9 \mathrm{Wm}^{-2}$ at TOA with average $\mathrm{AOD}_{675}$ value of $0.61( \pm 0.26)$. Compared to the DD class, this class has a relatively shorter range of DRF. This value of DRF is comparable to the mean DRF obtained by García et al. (2012) and Yoon et al. (2005) for similar biomass burning site in South America and South Africa, respectively. Compared to the DD and BB aerosol classes, the urban (UB) class exerts a smaller cooling effect. This class (urban) with average $\mathrm{AOD}_{675}$ of $0.38( \pm 0.23)$, rich in anthropogenic urban aerosol, is estimated to have a DRF value of $-11.7( \pm 7.5) \mathrm{Wm}^{-2}$. In a study by Yoon et al. (2005), similar values of DRF were obtained for US East Coast (Goddard Space Flight Center (GSFC)), a heavily populated urban area. With median $\mathrm{DRF}$ value of $-8.2 \pm 5.8 \mathrm{Wm}^{-2}\left(\mathrm{AOD}_{675}=0.29 \pm 0.21\right)$, the GF class has the least cooling effect at TOA. The GF class is believed to be rich in fossil fuel combustion emissions including sulfate and black carbon (Fawole et al., 2016a).

\section{Radiative Forcing Efficiency (RFE)}

The absolute magnitude of the DRF is dependent not only on the amount of radiation entering the atmosphere but also on the quantity of aerosol perturbing the atmosphere (Bush and Valero, 2003). For a better understanding of the

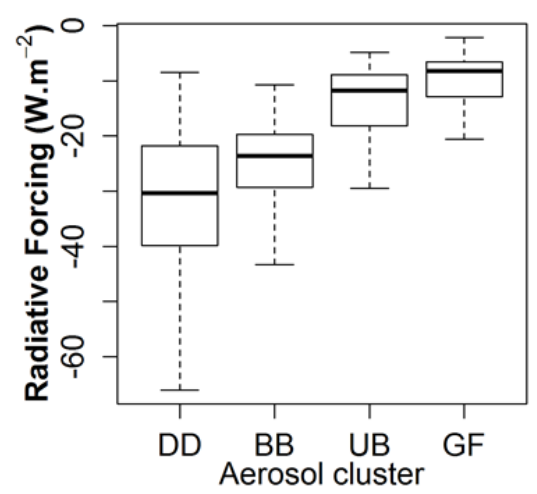

Fig. 4. Direct radiative forcing (DRF) at the TOA for the different aerosol classes.

Table 2. Mean monthly surface reflectance and cloud amount for study site.

\begin{tabular}{lllllllllllll}
\hline & Jan & Feb & Mar & Apr & May & Jun & Jul & Aug & Sept & Oct & Nov & Dec \\
\hline $\mathrm{R}_{\mathrm{s}}$ & 0.13 & 0.14 & 0.15 & 0.15 & 0.15 & 0.14 & 0.14 & 0.14 & 0.13 & 0.13 & 0.12 & 0.12 \\
Cloud amount & 0.22 & 0.35 & 0.35 & 0.35 & 0.35 & 0.35 & 0.35 & 0.35 & 0.35 & 0.35 & 0.35 & 0.15 \\
\hline
\end{tabular}


impact of aerosol optical depth (AOD) on the estimation of aerosol DRF, the radiative forcing efficiency (RFE) of the different classes was estimated using Eq. (4). Since RFE is independent of AOD, it is a useful tool to compare the forcing abilities of different aerosol types. As such, the influences of other variables, such as SSA, absorption and scattering properties, and surface albedo might become more evident (García et al., 2012).

Fig. 5 shows the variation of the RFE for the different aerosol classes. The natural aerosol, desert dust (DD), has the least average RFE of $-31.0 \pm 3.3 \mathrm{Wm}^{-2} \delta^{-1}$. The BB aerosol class, like the DD class, has a short range of RFE, but a higher mean RFE value of $-39.0 \pm 4.0 \mathrm{Wm}^{-2} \delta^{-1}$. The UB and GF aerosol classes have average RFE values of $-32.4 \pm 5.4$ and $-36.0 \pm 7.8$, respectively. The BB aerosol class has the highest median RFE value. These two classes (UB and GF), compared to the DD and BB aerosol classes, have relatively wider ranges of RFE. As such, aerosols in these two classes have the ability to perturb the earthatmosphere system more in this region.

Fig. 6 presents the relationship between DRF and aerosol optical depth $\mathrm{AOD}_{675}$ for the different aerosol types. The slope of best-fit line, shown in red, gives the average forcing efficiency, as estimated by Eq. (4). The regression equation for the plot and correlation of DRF and AOD values are also shown in red on Fig. 6. In Fig. 6, $\mathrm{N}$ is the number of days clustered into each aerosol class.

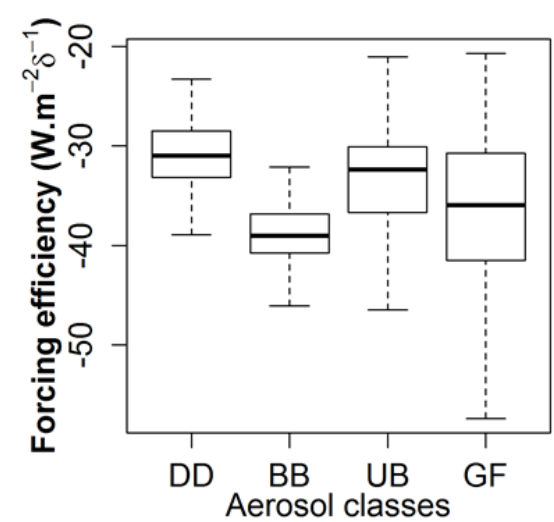

Fig. 5. Radiative forcing efficiency (RFE) for the different classes.
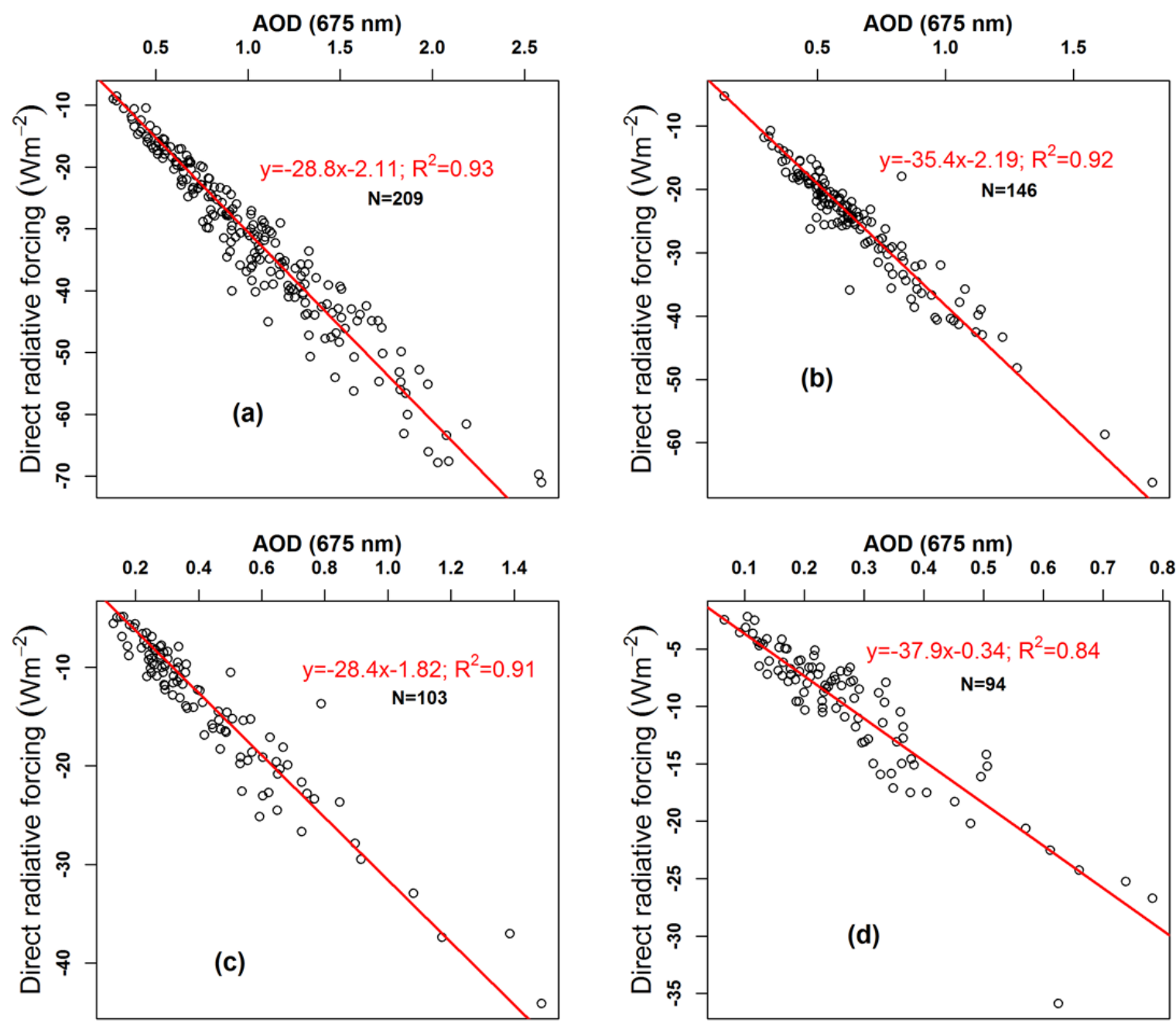

Fig. 6. The relationship between DRF and AOD (675 nm) for (a) Desert dust cluster, (b) Biomass burning cluster, and (c) Urban cluster and (d) Gas flaring cluster. 


\section{CONCLUSION}

The variations of aerosol optical and microphysical parameters-AOD, SSA, asymmetric parameter, Ångström exponent and backscatter fraction-were studied for the West African sub-region using AERONET retrievals from Ilorin, Nigeria. The DD aerosol class is characterised by high AOD and low AE. The BB aerosol class is characterised by high AOD and high AE, while the GF class is characterised by low AOD and high AE. The direct radiative forcing of the various dominant aerosol types was estimated using aerosol parameters from AERONET retrievals as inputs in a simplified radiative transfer equation proposed by Haywood and Shine (1995). Due to differences in methodologies and varying aerosol sources/nature, it is difficult to directly compare our results (average DRF values) with those from literature. Desert dust (DD) and biomass burning aerosols were found to be the most effective cooling aerosol in the region at the TOA. The UB and GF aerosol classes, which have been suggested as being rich in emissions from the combustion of fossil fuel (i.e., black carbon and sulphate), have less of a cooling effect. The more absorbing aerosols (GF and BB) show a higher forcing efficiency, and the GF aerosol class exhibits the largest variability in RFE. These results suggest the need for concerted efforts to adequately characterise and quantify emissions from real-world gas flares, as they make significant contributions to the radiative transfer in the earth-atmosphere system, particularly in oilrich regions, where gas flaring is persistent, continuous and substantial. To the best of our knowledge, this is the first estimate of DRF for the gas-flaring dominant aerosol class.

Findings from this study, especially as they relate to the GF cluster, suggest the need for an adequate understanding of the behaviour and transformation of atmospheric aerosol of gas flaring origin. A chemistry transport model with adequate schemes to simulate the behaviour of aerosols will be very appropriate for this proposed study.

\section{REFERENCES}

Alam, K., Shaheen, K., Blaschke, T., Chishtie, F., Khan, H.U. and Haq, B.S. (2016). Classification of aerosols in an urban environment on the basis of optical measurements. Aerosol Air Qual. Res. 16: 2535-2549.

Andrews, E., Sheridan, P., Fiebig, M., McComiskey, A., Ogren, J., Arnott, P., Covert, D., Elleman, R., Gasparini, R. and Collins, D. (2006). Comparison of Methods for Deriving Aerosol Asymmetry Parameter. J. Geophys. Res. 111: D05S04.

Andrews, E., Ogren, J., Bonasoni, P., Marinoni, A., Cuevas, E., Rodríguez, S., Sun, J., Jaffe, D., Fischer, E. and Baltensperger, U. (2011). Climatology of aerosol radiative properties in the free troposphere. Atmos. Res. 102: 365-393.

Anejionu, O.C., Blackburn, G.A. and Whyatt, J.D. (2015). Detecting gas flares and estimating flaring volumes at individual flow stations using MODIS data. Remote Sens. Environ. 158: 81-94.

Barry, R.G. and Chorley, R.J. (2009). Atmosphere, weather and climate. Routledge, USA.

Bibi, H., Alam, K. and Bibi, S. (2016). In-depth discrimination of aerosol types using multiple clustering techniques over four locations in Indo-Gangetic plains. Atmos. Res. 181: 106-114.

Bibi, S., Alam, K., Chishtie, F., Bibi, H. and Rahman, S. (2017). Observations of black carbon aerosols characteristics over an urban environment: Radiative forcing and related implications. Sci. Total Environ. 603: 319-329.

Blanchet, J.P. (1982). Application of the chandrasekhar mean to aerosol optical parameters. Atmos. Ocean 20: 189-206.

Bush, B.C. and Valero, F.P. (2003). Surface aerosol radiative forcing at Gosan during the ACE-Asia campaign. J. Geophys. Res. 108: 8660.

Charlson, R., Schwartz, S., Hales, J., Cess, R., Coakley, J., Hansen, J. and Hofmann, D. (1992). Climate forcing by anthropogenic aerosols. Science 255: 423-430.

Chylek, P. and Wong, J. (1995). Effect of absorbing aerosols on global radiation budget. Geophys. Res. Lett. 22: 929-931.

Cooke, W.F. and Wilson, J.J. (1996). A global black carbon aerosol model. J. Geophys. Res. 101: 1939519409.

Cooke, W.F., Jennings, S. and Spain, T. (1997). Black carbon measurements at mace head, 1989-1996. J. Geophys. Res. 102: 25339-25346.

Cornforth, R. (2012). Overview of the west african monsoon 20111. Weather 67: 59-65.

D'Almeida, G.A., Koepke, P. and Shettle, E.P. (1991). Atmospheric aerosols: Global climatology and radiative characteristics. A Deepak Pub, USA.

Delene, D.J. and Ogren, J.A. (2002). Variability of aerosol optical properties at four North American surface monitoring sites. J. Atmos. Sci. 59: 1135-1150.

Dubovik, O., Smirnov, A., Holben, B., King, M., Kaufman, Y., Eck, T. and Slutsker, I. (2000). Accuracy assessments of aerosol optical properties retrieved from Aerosol Robotic Network (AERONET) sun and sky radiance measurements. J. Geophys. Res. 105: 9791-9806.

Eck, T., Holben, B., Reid, J., Dubovik, O., Smirnov, A., O'Neill, N., Slutsker, I. and Kinne, S. (1999). Wavelength dependence of the optical depth of biomass burning, urban, and desert dust aerosols. J Geophys. Res. 104: 31333-31349.

Elvidge, C.D., Baugh, K.E., Ziskin, D., Anderson, S. and Ghosh, T. (2011). Estimation of gas flaring volumes using nasa modis fire detection products. NOAA National Geophysical Data Center (NGDC), Annual Report 8.

Elvidge, C.D., Ziskin, D., Baugh, K.E., Tuttle, B.T., Ghosh, T., Pack, D.W., Erwin, E.H. and Zhizhin, M. (2009). A fifteen year record of global natural gas flaring derived from satellite data. Energies 2: 595-622.

Elvidge, C.D., Zhizhin, M., Baugh, K., Hsu, F.C. and Ghosh, T. (2015). Methods for global survey of natural gas flaring from visible infrared imaging radiometer suite data. Energies 9: 14. 
Fawole, O., Cai, X.M. and MacKenzie, A. (2016a). Gas flaring and resultant air pollution: A review focusing on black carbon. Environ. Pollut. 216: 182-197.

Fawole, O.G., Cai, X., Levine, J.G., Pinker, R.T. and MacKenzie, A. (2016b). Detection of a gas flaring signature in the AERONET optical properties of aerosols at a tropical station in West Africa. J. Geophys. Res. 121: 14513-14524.

García, O., Díaz, J., Expósito, F., Díaz, A., Dubovik, O., Dubuisson, P. and Roger, J.C. (2012). Shortwave radiative forcing and efficiency of key aerosol types using AERONET data. Atmos. Chem. Phys. 12: 51295145.

Haywood, J. and Shine, K. (1995). The effect of anthropogenic sulfate and soot aerosol on the clear sky planetary radiation budget. Geophys. Res. Lett. 22: 603606.

Haywood, J. and Boucher, O. (2000). Estimates of the direct and indirect radiative forcing due to tropospheric aerosols: A review. Rev. Geophys. 38: 513-543.

Haywood, J.M. (1995). Model investigations into the radiative forcing of climate by anthropogenic emissions of sulphate and soot aerosol, University of Reading, United Kingdom, p. 247.

Hess, M., Koepke, P. and Schult, I. (1998). Optical properties of aerosols and clouds: The software package opac. Bull. Am. Meteorol. Soc. 79: 831-844.

Holben, B., Eck, T., Slutsker, I., Tanre, D., Buis, J., Setzer, A., Vermote, E., Reagan, J., Kaufman, Y. and Nakajima, T. (1998). Aeronet-A Federated Instrument Network and Data Archive for Aerosol Characterization. Remote Sens. Environ. 66: 1-16.

Holben, B., Eck, T., Slutsker, I., Smirnov, A., Sinyuk, A., Schafer, J., Giles, D. and Dubovik, O. (2006). Asiapacific remote sensing symposium, 2006, International Society for Optics and Photonics, pp. 64080Q-64080Q64014.

Horvath, H., Kasahara, M., Tohno, S., Olmo, F., Lyamani, H., Alados-Arboledas, L., Quirantes, A. and Cachorro, V. (2016). Relationship between the fraction of backscattered light and the asymmetry parameter. $J$. Aerosol Sci. 91: 43-53.

IPCC (2013). Climate Change 2013: The physical science basis. Contribution of Working Group I to the Fifth Assessment Report of the Intergovernmental Panel on Climate Change. Stocker, T.F, Qin, D., Plattner, G.K., Tignor, M., Allen, S.K., Boschung, J., Nauels, A., Xia, Y., Bex, B. and Midgley, B.M. (Eds.), Cambridge University Press, Cambridge, United Kingdom and New York, NY, USA.

Ite, A.E. and Ibok, U.J. (2013). Gas flaring and venting associated with petroleum exploration and production in the Nigeria's Niger Delta. Am. J. Environ. Prot. 1: 7077.

Kassianov, E.I., Flynn, C.J., Ackerman, T.P. and Barnard, J.C. (2007). Aerosol single-scattering albedo and asymmetry parameter from MFRSR observations during the ARM Aerosol IOP 2003. Atmos. Chem. Phys. 7: 3341-3351.
Kaufman, Y., Koren, I., Remer, L., Tanré, D., Ginoux, P. and Fan, S. (2005). Dust transport and deposition observed from the Terra-Moderate Resolution Imaging Spectroradiometer (MODIS) spacecraft over the Atlantic Ocean. J. Geophys. Res. 110: D10S12.

Knippertz, P., Evans, M.J., Field, P.R., Fink, A.H., Liousse, C. and Marsham, J.H. (2015). The possible role of local air pollution in climate change in West Africa. Nat. Clim. Change 5: 815-822.

Koch, D., Schulz, M., Kinne, S., McNaughton, C., Spackman, J., Balkanski, Y., Bauer, S., Berntsen, T., Bond, T.C. and Boucher, O. (2009). Evaluation of black carbon estimations in global aerosol models. Atmos. Chem. Phys. 9: 9001-9026.

Kokhanovsky, A. and Zege, E. (1997). Optical properties of aerosol particles: A review of approximate analytical solutions. J. Aerosol Sci. 28: 1-21.

Lafore, J.P., Flamant, C., Giraud, V., Guichard, F., Knippertz, P., Mahfouf, J.F., Mascart, P. and Williams, E. (2010). Introduction to the AMMA Special Issue on 'Advances in understanding atmospheric processes over West Africa through the AMMA field campaign'. Q. J. R. Meteorolog. Soc. 136: 2-7.

Law, K.S., Fierli, F., Cairo, F., Schlager, H., Borrmann, S., Streibel, M., Real, E., Kunkel, D., Schiller, C. and Ravegnani, F. (2010). Air mass origins influencing TTL chemical composition over West Africa during 2006 summer monsoon. Atmos. Chem. Phys. 10: 10753-10770.

Liousse, C., Galy-Lacaux, C., Ndiaye, S.A., Diop, B., Ouafo, M., Assamoi, E.M., Gardrat, E., Castera, P., Rosset, R. and Akpo, A. (2012). Real time black carbon measurements in West and Central Africa urban sites. Atmos. Environ. 54: 529-537.

Liousse, C., Assamoi, E., Criqui, P., Granier, C. and Rosset, R. (2014). Explosive growth in African combustion emissions from 2005 to 2030. Environ. Res. Lett. 9: 035003.

Mari, C.H., Reeves, C.E., Law, K.S., Ancellet, G., AndrésHernández, M.D., Barret, B., Bechara, J., Borbon, A., Bouarar, I. and Cairo, F. (2011). Atmospheric composition of West Africa: Highlights from the AMMA international program. Atmos. Sci. Lett. 12: 13-18.

Marshall, S.F., Covert, D.S. and Charlson, R.J. (1995). Relationship between asymmetry parameter and hemispheric backscatter ratio: Implications for climate forcing by aerosols. Appl. Opt. 34: 6306-6311.

Mathon, V. and Laurent, H. (2001). Life cycle of sahelian mesoscale convective cloud systems. Q. J. R. Meteorolog. Soc. 127: 377-406.

Myhre, G., Shindell, D., Bréon, F.M., Collins, W., Fuglestvedt, J., Huang, J., Koch, D., Lamarque, J.F., Lee, D., Mendoza, B., Nakajima, T., Robock, A., Stephens, G., Takemura, T. and Zhan, H. (2013). Anthropogenic and natural radiative forcing. In Climate Change 2013: The physical science basis. Contribution of Working Group I to the Fifth Assessment Report of the Intergovernmental Panel on Climate Change. Stocker, T.F., Qin, D., Plattner, G.K., Tignor, M., Allen, S.K., Boschung, J., Nauels, A., Xia, Y., Bex, B. and Midgley, 
B.M. (Eds.), Cambridge University Press, Cambridge, United Kingdom and New York, NY, USA.

NOAA (1998). Automated Surface Observing System (ASOS) Users' Guide, National Oceanic and Atmospheric Administration, USA.

Ogunjobi, K., He, Z. and Simmer, C. (2008). Spectral aerosol optical properties from AERONET Sunphotometric measurements over West Africa. Atmos. Res. 88: 89-107.

Pace, G., Sarra, A.d., Meloni, D., Piacentino, S. and Chamard, P. (2006). Aerosol optical properties at Lampedusa (Central Mediterranean). 1. Influence of transport and identification of different aerosol types. Atmos. Chem. Phys. 6: 697-713.

Pani, S.K., Wang, S.H., Lin, N.H., Lee, C.T., Tsay, S.C., Holben, B.N., Janjai, S., Hsiao, T.C., Chuang, M.T. and Chantara, S. (2016). Radiative effect of springtime biomass-burning aerosols over northern Indochina during 7-SEAS/BASELInE 2013 Campaign. Aerosol Air Qual. Res. 16: 2802-2817.

Ramachandran, S. and Kedia, S. (2010). Black carbon aerosols over an urban region: Radiative forcing and climate impact. J. Geophys. Res. 115: D10202.

Rana, S., Kant, Y. and Dadhwal, V. (2009). Diurnal and seasonal variation of spectral properties of aerosols over Dehradun, India. Aerosol Air Qual. Res. 9: 32-49.

Reeves, C., Formenti, P., Afif, C., Ancellet, G., Attié, J.L., Bechara, J., Borbon, A., Cairo, F., Coe, H. and Crumeyrolle, S. (2010). Chemical and aerosol characterisation of the troposphere over West Africa during the monsoon period as part of AMMA. Atmos. Chem. Phys. 10: 7575-7601.

Rizzo, L.V., Artaxo, P., Muller, T., Wiedensohler, A., Paixao, M., Cirino, G.G., Arana, A., Swietlicki, E., Roldin, P., Fors, E., K. T. Wiedemann, Leal, L.S.M. and Kulmala, M. (2013). Long term measurements of aerosol optical properties at a primary forest site in Amazonia. Atmos. Chem. Phys. 13: 2391-2413.

Roberts, G., Wooster, M. and Lagoudakis, E. (2009). Annual and diurnal african biomass burning temporal dynamics. Biogeosciences 6: 849-866.

Sheridan, P., Jefferson, A. and Ogren, J. (2002). Spatial variability of submicrometer aerosol radiative properties over the Indian ocean during indoex. J. Geophys. Res. 107: INX2 10-11-INX12 10-17.

Sheridan, P.J. and Ogren, J.A. (1999). Observations of the vertical and regional variability of aerosol optical properties over central and eastern North America. $J$. Geophys. Res. 104: 16793-16805.

Stier, P., Feichter, J., Roeckner, E., Kloster, S. and Esch, M. (2006). The evolution of the global aerosol system in a transient climate simulation from 1860 to 2100 . Atmos. Chem. Phys. 6: 3059-3076.

Sultan, B. and Janicot, S. (2000). Abrupt shift of the ITCZ over West Africa and intra-seasonal variability. Geophys. Res. Lett. 27: 3353-3356.

Tiwari, S., Tiwari, S., Hopke, P., Attri, S., Soni, V. and Singh, A.K. (2016). Variability in optical properties of atmospheric aerosols and their frequency distribution over a mega city "New Delhi," India. Environ. Sci. Pollut. Res. 23: 8781-8793.

Todd, M.C., Washington, R., Martins, J.V., Dubovik, O., Lizcano, G., M'bainayel, S. and Engelstaedter, S. (2007). Mineral dust emission from the Bodélé Depression, northern Chad, during BoDEx 2005. J. Geophys. Res. 112: D06207.

USEPA (2012). Report to congress on black carbon. EPA450/R-12-001, United States Environmental Protection Agency, Research Triangle Park, NC.

Verma, S., Prakash, D., Srivastava, A.K. and Payra, S. (2017). Radiative forcing estimation of aerosols at an urban site near the thar desert using ground-based remote sensing measurements. Aerosol Air Qual. Res. 17: 1294-1304.

Virkkula, A., Levula, J., Pohja, T., Aalto, P., Keronen, P., Schobesberger, S., Clements, C.B., Pirjola, L., Kieloaho, A.J. and Kulmala, L. (2014). Prescribed burning of logging slash in the boreal forest of Finland: emissions and effects on meteorological quantities and soil properties. Atmos. Chem. Phys. 14: 4473-4502.

Wang, J., Xia, X., Wang, P. and Christopher, S.A. (2004). Diurnal variability of dust aerosol optical thickness and Angström exponent over dust source regions in China. Geophys. Res. Lett. 31: L08107.

Wiscombe, W. and Grams, G. (1976). The backscattered fraction in two-stream approximations. J. Atmos. Sci. 33: 2440-2451.

Yang, X., You, Z., Hiller, J. and Watkins, D. (2016). Updating and augmenting weather data for pavement mechanistic-empirical design using ASOS/AWOS database in Michigan. Int. J. Pavement Eng. 19: 10251033.

Yoon, S.C., Won, J.G., Omar, A.H., Kim, S.W. and Sohn, B.J. (2005). Estimation of the radiative forcing by key aerosol types in worldwide locations using a column model and AERONET data. Atmos. Environ. 39: 66206630 .

Received for review, December 26, 2017 Revised, July 5, 2018 Accepted, July 31, 2018 